\title{
Thailand four years after the coup: the struggle against the dissenters
}

\author{
Poowin Bunyavejchewin*
}

After the 2006 coup d'état, there were many unusual incidents in Thailand, some of which involved considerable bloodshed, which originated from clashes between those in power and dissenters. This article examines how political institutions in Thailand are structured, and the author argues that, in order to effectively assess the state of Thai politics after the coup, an analysis of the structures of political legitimacy in the country is essential. The author will be exploring the way in which political legitimacy is generally determined by the established power holders, especially the monarchy and its allies. The ideologies and beliefs of recent dissenters will also be examined in detail.

\section{Introduction}

On September 11, 2010, Prime Minister Abhisit Vejjajiva was faced with difficult questions from university students in a special Government House meeting. One of the students asked him to resign or prove his innocence with regard to the deaths of antigovernment demonstrators brought about through the justice system. He, however, insisted on his innocence. In fact, since he came to power, there have been many deaths and injuries caused by his government's actions in quelling dissent, and he has been strongly supported in this by Thai elites and the middle classes.

The support of these elites has operated as a license for those in power to practice repression of dissent. The achievement of democratic consensus through majority voting has become gradually less important. Various influential members of the Thai elites and the middle classes have repeatedly claimed that as the population in the rural areas and many lower middle class people are relatively uneducated, they have become the victims of unscrupulous politicians who want to "buy" their votes. It has been argued that the votes of poorer people should not have equal value to those of the elites and the middle classes.

It has also been claimed that politicians are naturally unethical and corrupt. However, the politicians approved in direct and indirect ways by the elites and the monarchy have been labeled "good persons" (khondee). For instance, General Surayud Chulanont was made prime minister by those who launched the coup rather than by the electorate. Yet General Prem Tinsulanonda, the Head of the Privy Council, has confirmed that he is one of the khondee who has worked honestly for the nation for a long time, and thus an appropriate choice as Prime Minister. Thus Prem, a highly

\footnotetext{
* Poowin Bunyavejchewin is a graduate student at Thammasat University, Thailand. He obtained his MA in International Politics from the University of Hull, UK.

Contact: P.Bunyavejchewin@2009.hull.ac.uk
} 
influential figure among the middle classes, has taken it upon himself to decide who is a "good person," rather than allowing the people to elect a suitable politician. From Prem's point of view, an election cannot always be considered a legitimate means of gaining political power. Since the coup on September 19, 2006, which brought about the downfall of the Thaksin government, the means of obtaining political legitimacy has been moving backward towards the royal absolutist tradition. Therefore, in order to understand the current state of Thai politics, comprehending the dynamics of political legitimacy in the country is essential.

It can be argued that, in the context of Thailand, neither political institutions nor political culture define political legitimacy, but that the shape of both political institutions and political culture are consequences of the function of the structure of legitimacy. This is why conflicts over determining the structure of legitimacy have occurred throughout the history of Thai politics. The current political crises are no exception.

In this article, the political crises in Thailand since the coup in 2006 are examined in detail, with particular reference to the present elitist structure of legitimacy and how that structure upholds the status of those currently in power. The way in which political legitimacy has been claimed in order to preserve the status of those in power has also been analyzed, and the negative consequences of this have been examined.

\section{Brief Background to the Thai Political Crises}

Thailand has returned to an authoritarian regime since the coup of September 19, 2006, which was led by General Sonthi Boonyaratglin. The coup was also strongly supported by the Bangkok-based middle classes, the monarchy, and the social elites, of which General Prem Tinsulanonda is the major symbol. Despite the fact that two democratic governments had previously been established through elections, neither could bring the military under control. On the contrary, the military had more influence than the governments. The September 19, 2006 coup was a de jure coup d'état. However, a de facto coup d'état occurred after that time.

The main reason that Thaksin Shinawatra was ousted from office in 2006 was neither corruption nor capital cronyism, but the need to change the rule of the existing structure of legitimacy. His behavior and policies challenged the traditional practices of Thai politicians. For example, Thaksin's populist policies were seen as suspect because it was thought that they might replace royal projects in rural areas that had been under the royal sphere of influence.

A clarification of the status and role of the monarchy and its network of allies is essential in order to understand Thai politics. The Thai monarchy is extraordinarily different from monarchies in other democratic regimes, which have a monarch as head of state (Ivarsson and Isager 2010, 1-26). Although the constitution states that the monarchy is beyond politics, in reality this does not prevent it from continuing to exercise considerable political power. The monarchy has come to be regarded as more and more of a sacred institution since the end of the political crisis of 1973, which the monarch had a prominent role in resolving. Members of the monarchy have been portrayed as tender-hearted angels who devote their lives to the Thai people, especially in rural areas, but the benefits of this for rural people are doubtful. Their role as a "divine" institution provides them with an efficient weapon for protecting their status and their role as well as those of their allies: lèse majesté law. The charge of insulting the monarchy has been used to effectively control and eliminate political opponents who disagree with the monarchy's status and role (Streckfuss 2011). Thus it would not be an 
exaggeration to state that the monarchy, especially the present king, are the actual power holders in the country, but this is officially unsayable and unthinkable in Thailand.

Two democratic governments, led by Samak Sundaravej and Somchai Wongsawat, were elected after the 2006 coup, but both found governing the country impossible, so both had to leave office. Both Samak and Somchai were perceived as Thaksin's nominees. Hence, their governments were threats to the existing structure of legitimacy.

The de facto coup d'état occurred late in 2008 after the dissolution of the People's Power Party. The de facto coup was led by General Anupong Paochinda, the Commander in Chief of the Royal Thai Army, who invited politicians to a meeting with him after a shift in the allegiance of political factions in the House of Representatives. At this point Abhisit Vejjajiva became prime minister. There is no doubt that Abhisit's government is backed by the military, the elites, and the monarchy. However, this has stirred up animosity and has sparked a massive protest by the pro-Thaksin camp, which consists of rural residents and lower-middle class people, as well as anti-coup protesters. This camp has been called the Red Shirts. However, the official name is the National United Front of Democracy Against Dictatorship (UDD).

Opposing the Red Shirts are the Yellow Shirts or the People's Alliance for Democracy (PAD). This group consists of middle class people, members of elites, and monarchists who supported the coup by the military in order to protect the status quo in the existing power structure (Pathmanand 2008). For the elites and the monarchists, ousting Thaksin and his allies was necessary for preserving their power in the current structure of legitimacy. The Yellow Shirts held massive protests from 2005 through 2008. In addition, there is a group called the Multi-Color Shirts, who are really not very different from the Yellow Shirts.

New, massive protests have been out of control since 2009. The Red Shirts started heavy protests in Bangkok and have started to resort to violence, which has been escalating. A number of casualties have resulted from the political violence, many of which have been caused by the government, and some academics have stated that the situation, especially in April and May 2010, comprises not just a series of riots but a civil war.

After heavy subjugation by the government, the Red Shirts officially ceased their protests. However, the leaders could not control the protesters, and the aftermath was not only the ruin of many buildings and department stores in Bangkok but also the burning of city halls in many provinces, especially in the North and North East, where there were several notable cases of arson..

Although the government has attempted to call for unity, especially in television broadcasts, and repeatedly claim political legitimacy to quell protestors, its efforts do not appear to be working, because its repression of the protesters has needed to be enforced through terror. Many protesters and other dissenters are still asserting government responsibility for the deaths which have occurred during the protests, although the government has made an effort to show its sincerity. For instance, the government has appointed many commissions to investigate what happened. However, these commissions have been accused of being prejudiced. A great many members of the political opposition and potential dissenters have been placed in detention indefinitely by emergency decree without specific allegations being made against them. Abhisit's government, however, is still legitimate from the perspective of many members of the middle classes, the social elites and the monarchists and their network. 
Because his government has not challenged but conserved a core feature of the existing structure of legitimacy, they have not violated the version of political legitimacy supported by those in power.

\section{Political Legitimacy and Its Structure}

Dynamic though the structure of legitimacy is, according to Alagappa, it can be defined as "the belief by the governed in the ruler's moral right to issue commands and the people's corresponding obligation to obey such commands. Political legitimation is an interactive process between rulers and ruled. Conceived as an outcome of this process, legitimacy is contingent, dynamic, and continuously defined. Its cultivation must therefore be unending. As the interaction between ruler and ruled lies at the heart of the legitimacy question, it must be framed in the context of a specific society at a specified time." (Alagappa 1995, 29)

The structure of legitimacy consists of four elements: shared norms and values, conformity to established rules, the proper use of state power, and the consent of the governed (Alagappa 1995, 14-24). These elements are not separate but interrelated. In a developing country, shared norms and values are used by those in power to manipulate the established rules and to make them function efficiently in a highly authoritarian way.

Ordinary people are often not aware that shared norms and values can be manipulated to create political constructs and work as political instruments. It can be argued that there is really no difference between shared norms and values and ideology. As Althusser states “...Ideology comprises representations, images, signs, etc., but these elements considered in isolation from each other, do not compose ideology. It is their systematicity, their mode of arrangement, and combination that gives them their meaning; it is their structure that determines their meaning and function." He also states that ideology "is intelligible only through its structure." (Althusser 1997, 26) Therefore, as with ideology, shared norms and values are identifiable only in specific times and places. In any specific time or place, shared norms and values can form part of a political and ideological construct. Such a construct does not have to be static, but can play a transforming role in the case of a transition of power being effected.

New power holders need to construct their own new version of shared norms and values in order to enhance general conformity to the newly defined proper use of power, and to de-legitimize the old one. Last but not least, it is hardly possible to install the new construct at once because a process of installation within what Althusser calls the "ideological state apparatus" requires a period of time to instill new shared norms and values.

Shared norms and values can, as mentioned above, ameliorate the exercise of state power. Power, however, is a contested concept. In this article, the concept developed by Steven Lukes is followed. This is a radical, three-dimensional concept of power (Lukes 2005, 25-38). Power, Lukes explains, can be exerted in a way that leads the ruled to consciously do what the ruler wishes. This is not merely an exercise of power over others or a means of preventing those being ruled from what doing they want. The notion of power can be defined in a broad sense, from the use of force through to thought control. And the latter, for the ruled, is always not perceived as a function of power. However, exerting physical power may bring about unfavorable consequences for the political holders. Using physically violent means can erode the legitimacy of their regime. Hence, the exercise of state power can also impact the level 
of conformity of the governed, but achieving some consent for imposing that conformity is important in establishing effective power.

Selecting particular means of using state power may impact the level of general conformity to established rules. In order to control nonconformists, especially when they turn to street protests or violent action, the holders of power may choose the use of force to mitigate the crisis. However, the exercise of state power can turn out to be a two-edged sword if the use of limited force is not considered by the power holders.

All these elements have an influence on the consent of the governed and vice versa. Consent is significant in a democratic regime, although it is also not irrelevant in other types of regime. However, in a totalitarian regime, its limits may be difficult to identify. Consent, in general, can be defined as an acceptance of the right of power holders to issue orders and the undertaking of an obligation by the ruled to obey such orders. Therefore, it must not be confused with conformity. In contrast to consent, conformity does not require a grounded faith in the rights of specific power holders and established rules. It is based on the idea that something will be given in return, such as a reward or some punitive prevention. Widespread political insubordination is a reflection of a lack of consent, which can corrode the legitimacy of power holders and their regime.

As the four elements are interconnected, the weakness of one does not mean the end of overall legitimacy as long as it can be compensated by another. Shared norms and values, however, have more capital, and can be seen as being supplementary to other elements in the consolidation of the structure of legitimacy. Last but not least, in understanding political legitimacy, a consideration of all four elements in the structure is necessary, and a dichotomous analysis of black and white is completely superficial. Instead, the degrees of complexity, dynamism, and variegation need to be studied.

\section{The Royalist Version of Political Legitimacy and Its Defenders}

At the present time, there are many criticisms by academics, activists, and the political opposition, such as the Red Shirts protestors, regarding the political legitimacy of the current government. Most of these groups have accused Abhisit and his regime of illegitimacy because of the way it abused power in launching a violent crackdown on the Red Shirts protestors. Besides this turbulent action, an emergency decree was issued, but this can be seen as merely an instrument to maintain the current regime and get rid of political opposition.

It is undeniable that the present regime is totally illegitimate in a democratic context. However, it can be argued that such criticism is not really valid in the context of Thailand because of the uniqueness of Thai-style democracy. Furthermore, Thai-style democracy is not immobile; yet, its essence depends upon the structure of legitimacy as determined by the power holders. In spite of the dynamic of democracy in Thailand, Thai-style democracy as defined by Marshal Sarit Thanarat, the Thai royalist dictator who was in power between 1958 and 1963, has been partially inherited by the present version of democracy. Sarit has stated that democracy must match the following conditions and that it must (Sukatipan 1995, 204):

1. Fit into the Thai way of life. The constitution must not be a duplication of those of the West; it must be practical and relevant to the Thai environment. Elections are thus not necessary.

2. Contribute to political stability 
3. Be accompanied by a liberal economic system that is minimally guided by the government

4. Uphold the monarchy

5. Facilitate national development

These conditions, except for the second one, are still the basis of the present Thai-style democracy. This also indicates that the existing structure of legitimacy is dominated by the current power holders, the monarchy and its allies as well as the elites. Although the present structure needs to be variable in order for the power holders to accommodate altered circumstances, there are also new forces at large, which have emerged through socioeconomic changes, and which defy the existing power structures.

Two of the factors that caused the Siamese revolution in 1932 are social change and economic depression. Since the modernization of the King Chulalongkorn era (1868-1910), many members of royal family and bureaucrats had been sent to study in Europe, which, at that time, was experiencing the rise of democracy. Western-educated bureaucrats felt that royal absolutism was illegitimate and obsolete for Siam. Also, lowranking soldiers were also influenced by democratic thoughts, which came with modernization. Consequently, there was a rebellion led by low-ranking soldiers in 1912. In spite of its failure, the absolutist royal regime was finally overthrown in the revolution of 1932, which was led by a group of Western-educated soldiers and civilians called "the People's Party" (Khana Ratsadon). The great depression in 1929 was also a significant destabilizing factor, as were the social transformations that de-legitimized the absolute monarchy in Siam and eventually caused its collapse.

In the case of the 1932 revolution, the Western-educated and reformist bureaucrats represented the new force of modernization, and the existing structure of legitimacy could not respond to their demands. However, it did maintain a sense of royal superiority, although the lack of consent and shared norms and values among bureaucrats, which is critical for a monarchical regime, eroded King Prajadhipok's legitimacy and resulted in the end of his reign.

However, since 1973, the monarchy has been reviving and its members have gradually cultivated their roles as "tender-hearted angels" and "salvagers" who can provide guidance when the country is at a crossroads. The monarchy has also compromised with many powerful groups through its network of patron-client relations (McCargo 2005). Also, it has been quite willing to be the instrument of militant dictators from time to time. For instance, in October 1976, a massacre of unarmed protestors, mostly students and workers, who were accused of lèse majesté at Thammasat University and the following coup d'état led by the right-wing were supported and endorsed by the monarchy (Alagappa 1987, 42). This can be proved by examining the roles of members of the royal family in that period. For example, the royal figures visited the village scouts, a countrywide organization that the King and Queen of Thailand have sponsored for the general public since 1972 in order to promote national unity (Muecke 1980, 407), who they patronized, and who had a significant role in exterminating the peaceful protesters. Nevertheless this was not entirely unexpected because the rapid political change demanded by the progressive protesters was viewed by the king as a threat to the monarchy (Alagappa 1987, 42) as it could have affected the structure of legitimacy and therefore, the status of the monarchy.

Evidence in the massacre of October 6,1976 remains concealed and has been practically erased from the political history of Thailand, because of what it reveals about the conduct of the monarchy at that time. Although many years have passed, the occurrences in 1976 have had many features in common with recent incidents. In 
particular, shared norms and values can be observed and a similar exercise of state power has been conducted. Furthermore, many elements of the ongoing situation are analogous with the earlier political events. Thus it is very necessary to refer to Thai political history.

The development of the current political situation can be traced back to the 1997 financial crisis, which severely affected the Thai economy and arrested Thailand's dream of becoming the fifth Asian tiger. In December 1997, King Bhumipol reiterated and expanded the concept of the Sufficiency Economy as a direction for the Thai people. His role as an enlightened salvager once again enhanced his prestige and consolidated the status of the monarchy that already had been firmly settled in the structure of legitimacy dominated by itself. Although the definition of the Sufficiency Economy is unclear, its essence vaguely resembles communitarianism. Its key idea is that everyone should have enough to get by, and all should accept their position in the social hierarchy. This was neither a theory nor a philosophy but an instrumental doctrine. The idea of the Sufficiency Economy remains a vital feature of existing shared norms and values.

Aside from the concept of the Sufficiency Economy, Buddhism is also important. In Thailand, Buddhism is not always a civic religion, although it tends to be mentioned repeatedly by many public figures (McCargo 2009). However, it is always a useful instrument for power holders and can function as a political tool (Suksamran 1982, 24-26). The Buddha's doctrine, especially belief in karma and destiny, is frequently used by power holders to justify limiting the governed in advancing their socioeconomic status. And it has also been used to support the king's economic concepts.

Buddhist monks have played important roles as moral arbiters for the power holders. It should be mentioned that some famous Thai monks, who have high social capital, have a similar status to singers or movie stars. Whether intentionally or not, these "Buddhist stars" can give moral support to the established structure of legitimacy. W. Vajiramedhi, one famous monk, for example, often calls for unity without calling for justice for victims of government repression and openly supports the Abhisit government. Monks have also played important political roles throughout history. For instance, Kittivudho Bhikkhu, the monk who was the leader of paramilitary in the massacre of 1976, was a right-wing ideologue, and became a popular figure among rightists after he issued his notorious motto that killing communists is not a sin (Keyes 1978, 153-158; Suksamran 1982, 132-157). The accusation of being a communist, at the time of Cold War, was a weapon often used to de-legitimize political opposition. Being a communist was seen as the opposite to the ideal of Thai nationhood or "Thainess."

Most people take the concept of a nation for granted and suppose that it has existed for a long time. However, according to Anderson (2006), a nation is an imagined political community. Therefore, it is not a natural but a social construct. The concept of nationhood is similar to that of a nation in that it is not a natural construct but an artifact; thus, it is problematic because it is not static or monolithic. As soon as a nation is constructed, some individuals will be excluded, despite living within the state's boundaries. Nationhood divides people into "us" and "them" or "ourselves" and "others." The "others" may be in danger because nationhood may be seen as sacred. The "others" may resemble the iconoclasts of the Middle Ages. In this sense, nationhood is very similar to a religion that aims to make people believers or conformists without doubt or question (Bunyavejchewin 2010). 
Thai nationhood, or Thainess, is a highly problematic concept. Thongchai Winichakul, a prominent Thai historian, noted that Thainess has never been clearly defined. However, what is not Thai has often been identified. From this point of view, Thainess is obviously apparent when otherness can be identified. Therefore, the latter is essential to the former. Thongchai calls this process negative identification (Winichakul 2004, 5-6).

Apart from negative identification, there is also positive identification (Winichakul 2004, 4), which refers to the selection by power holders of some elements or norms which may define Thainess. For example, King Vajiravudh declared that the Thai nationhood was the monarchy. Thus, his version of Thainess gave precedence to loyalty to the monarchy. Even though the power holders prescribed what Thainess was, negative identification is still important to enhance the obvious appearance of Thainess.

Thainess is an efficient political tool for power holders so that they can maintain and enhance the existing structure of legitimacy. For instance, King Chulalongkorn attempted to popularize his version of Thai nationhood, in order to enhance the legitimacy of his throne and to sustain his status among rulers and subordinates (Chachavalpongpun 2005, 5). Thus, the function of Thainess is not only to preserve and increase the power holders' structure of legitimacy, but it can also be a powerful weapon for eradicating political opposition and eliminating doubts and arguments.

These three elements, namely the Sufficiency Economy, Buddhism, and Thainess, are the main ingredients of the present shared norms and values of what is called "Nation, Buddhism (religious), and Monarchy." These shared norms and values are seen as being sacred and unquestionable and have been viewed as the proper and natural form of morality that has made the governed, especially rural residents, give their consent to the power holders' authority. Though there have been political activists who have antagonized and challenged the existing political legitimacy, the power of fear has often been exerted to force such people into conformity. This has often been seen as legitimate because the challenger's behaviors did not fit with the existing structure of legitimacy.

The rise of Thaksin in 2001 made the power holders and elites anxious that existing political legitimacy could be eroded and that their status was in danger. The businessman Thaksin's government presented populist policies to the lower class and lower middle class people who had been neglected by all previous governments and by the power holders (Phongpaichit and Baker 2008). Before his government came to power, they had been excluded from the political system, and had been treated as beggars who could do nothing except wait for mercy from the power holders. Thaksin's populist policies were in extreme contrast to the king's concept of "sacred economics." In contrast to the Sufficiency Economy, the populist policies promoted the targeted group, the lower and lower middle classes, as entrepreneurs on different levels. This meant that their status and role in the existing structure would be transformed. In addition, these policies went against Buddhist doctrine in that they did not stress the idea of surrendering to destiny.

Despite the fact that the outcome of these populist policies is still unclear, lower and lower-middle class people have been certainly become more active in the political system. Thus the existing structure of legitimacy was questioned as the old shared norms and values could no longer secure the consent of the governed. In the eyes of the old power holders, toppling Thaksin and his government was a necessity in order to prevent more erosion of the existing structure of legitimacy.

At first the power holders had thought that ousting Thaksin and his network from the power would be enough to save their structure of legitimacy, but later they found that this had been inadequate as the lower classes' and lower middle classes' way 
of thinking has been changed dramatically. Whatever Thaksin's merits as an apolitical figure, his government certainly challenged established norms and values.

It can be argued that, as a result of these changes, the old shared norms and values have been changed, and that the automatic consent of lower and lower-middle class people is coming to the end. Thus the power holders and elites and their allies in Abhisit government need to make them conform to established rules at all costs. Otherwise their version of political legitimacy and its structure will be weakened irremediably.

The subjugation of the Red Shirt protestors is predicable if it is understood as a defense of established political legitimacy. However, the excessive exercise of state power may ultimately have a reverse effect on the structure. Though the power holders may succeed at present in making the ruled surrender, sooner or later a new antagonist will emerge as the existing structure of legitimacy gradually becomes illegitimate, due to not only the challenges of antagonists but also to the action of power holders that delegitimize their status.

\section{Conclusion}

Four years after the coup, Thailand is in a state of conflict between power holders who struggle to preserve the existing political legitimacy and dissenters, namely lower class and lower middle class people, who demand changes in the present structure. As all four elements of the structure of legitimacy are obviously being weakened, it can be argued that the current political legitimacy is rapidly declining. Even though the endeavor of power holders and its defenders was accomplished in controlling the protestors, the existing structure of legitimacy is eventually going to collapse. The only way those currently in power will be able to survive will be to compromise with new forces, as other power holders did in the past. Otherwise the end of their legitimacy will soon be at hand.

\section{References}

Alagappa, Muthiah. 1987. The National Security of Developing States: Lessons from Thailand. Dover, Mass.: Auburn House.

Alagappa, Muthiah. 1995. "The Anatomy of Legitimacy." In Political Legitimacy in Southeast Asia: The Quest for Moral Authority, edited by M. Alagappa, 11-30. Stanford: Stanford University Press.

Althusser, Louis. 1997. Philosophy and the Spontaneous Philosophy of the Scientists \& Other Essays. London and New York: Verso.

Bunyavejchewin, Poowin. 2010. "Constructing the 'Red' Otherness: The Role and Implications of Thainess on Polarised Politics." ASEAS - Austrian Journal of South-East Asian Studies 3 (2): 241-248.

Chachavalpongpun, Pavin. 2005. A Plastic Nation: The Curse of Thainess in Thai-Burmese Relations. Lanham, MD: University Press of America.

Ivarsson, Søren, and Lotte Isager. 2010. "Introduction: Challenging the Standard Total View of the Thai Monarchy.” In Saying the Unsayable: Monarchy and Democracy in Thailand, edited by I. Søren, and L. Isager, 1-26. Copenhagen: NIAS Press.

Keyes, Charles F. 1978. "Political Crisis and Militant Buddhism in Contemporary Thailand." In Religion and Legitimation of Power in Thailand, Laos, and Burma, edited by B. L. Smith, 147-164. PA: ANIMA Books.

Lukes, Steven. 2005. Power: A Radical View. $2^{\text {nd }}$ edn. Basingstoke: Palgrave Macmillan. 
McCargo, Duncan. 2005. "Network Monarchy and Legitimacy Crises in Thailand." The Pacific Review 18(4): 499-519.

McCargo, Duncan. 2009. "The Politics of Buddhist identity in Thailand's deep south: The Demise of civil religion?." Journal of Southeast Asian Studies 40(1): 11-32.

Muecke, Marjorie A. 1980. “The Village Scouts of Thailand.” Asian Survey 20(4): 407-427.

Pathmanand, Ukrist. 2008. “A Different Coup d' État?.” Journal of Contemporary Asia 38(1): 124-142.

Phongpaichit, Pasuk, and Chris Baker. 2008. "Thaksin's Populism.” Journal of Contemporary Asia 38(1): 62-83.

Winichakul, Thongchai. 2004. Siam Mapped: A History of the Geo-body of a Nation. Chiang Mai: Silkworm Books.

Streckfuss, David. 2011. Truth on Trial in Thailand: Defamation, Treason, and Lèse-Majesté. Abingdon: Routledge.

Sukatipan, Saitip. 1995. "Thailand: The Evolution of Legitimacy." In Political Legitimacy in Southeast Asia: The Quest for Moral Authority, edited by M. Alagappa, 193-223. Stanford: Stanford University Press.

Suksamran, Somboon. 1982. Buddhism and Politics in Thailand. Singapore: ISEAS. 